\title{
The Challenges in Building a Legal State in the Republic of Macedonia
}

\author{
Prof. Dr. Mersim Maksuti, \\ Professor of Constitutional Law at the SUT, \\ Tetovo, Macedonia
}

\begin{abstract}
The Establishment and the consolidation of the legal state in the Republic of Macedonia still remains the main challenge and a primary issue which comes into view continuously during the functioning and the governance of this country, although we are facing the third decade of democratic transition since the fall of communism in these regions. By a legal state in Macedonia we understand the system in which the state authorities in this country, and in particular the executive and administrative authorities, though restricted to its legal norms (the constitution and the law) which guarantee the inviolability of fundamental human rights and freedoms of its citizens and the democratic functioning of political power, their implementation in practice nevertheless continues to represents a major difficulty that the country faces. The need of a functional legal state in Macedonia is still far from its implementation and in consistency with the theory of Hans Kelsen about the legal state. According to him, in the territorial region of a state there should be a single lawful, legitimate and sovereign order: that of the state: all the legal norms, directly or indirectly, derive from the state and those are valid only when incorporated in its lawful order, by thoroughly respecting their intentions. "The state represents the overall legal order, its law, being the highest, is the single true law". ${ }^{1}$ We shall stop and focus on some of the main criteria, principles and pillars on which it relies, respectively on those which condition and enable the functioning of a legal state in Macedonia. These are the criteria and principles which are also accepted by the judicial-constitutional concept in general. Firstly, we will examine the respect of the principle of constitutionality and legality, the respect of the basic human rights and freedoms in this country: the free and democratic elections, independent courts etc.
\end{abstract}

Keywords: law, judiciary, courts, rule of law, government, human rights and freedoms, free media, elections, constitution, corruption.

\section{Introduction}

The respect of the principle of constitutionality and legality is an important element that characterizes Macedonia as a legal state and its functioning according to the laws. We will view the respect of the principle of constitutionality from the angle of all the legal acts issued by Macedonia, and whether these are in accordance with the constitution of this country. In addition, the principle of legality will be analyzed from the aspect of whether all the state government institutions are in accordance with the laws of this country, namely the state administration institutions.

The constitutional restriction of power denotes the power within the limits of the law, respectively the power that is limited by the constitution in its formal or material aspect: "The law which doesn't restrict the actions of the government does not deserve even a minute of commitment towards it". ${ }^{2}$

The violation of the principle of legality represents a frequent practice of the functioning of the state governmental institutions and democracy in Macedonia.lllegality of the work of state institutions often causes incompatibility among legal acts (bylaws) and its implementation in practice in accordance to the law, as a higher legal act.The violation of the principle of legality occurs often in Macedonia, both in a material and a formal sense.

Cases of lawlessness in its material sense, first of all emerge in the work of the administrative institutions of this country. It often occurs that the institutions of the state administration, during their line of work when issuing the by-laws decisive about the rights and obligations of the citizens, issue by-laws which are not in compliance with the law and the pragmatic way of their implementation.

${ }^{1}$ Hans Kelzen, Theorie pure du droit, Dalloz, 1964

2 Leon Digi, Traite de droit constitutionnel, tome I, 3 ed, Paris, 1927, pp. 98-99 
This method of functioning of the state administration in Macedonia appears mostly as a result of the lack of de-politicization. The political influence continues to be present and this is the main factor which influences the decision-making of administration bodies, as well as its personnel policy. Only a de-politicized administration may exercise its duties properly and consistent to the implementation of the laws in Macedonia and rightful implementation of the rights and obligations of the citizens of this country.

Republic of Macedonia needs to focus more on the quality and respect of the laws than on the quantity. There may be many laws in a country, but no legality. This was nicely emphasized by the theorist Tacit at the beginning of our era "The more corrupt the state, the more numerous the laws" (Corruptissima res publica, plurimae leges).

Another important concern in Macedonia that leads to challenging the legal state is the control on the constitutionality of the laws as one of the issues on which depends the implementation of the constitutional principle in practice. The control on the constitutionality of the laws in this country needs to include more control on the compliance of the laws with the Constitution of Macedonia, both in the material and formal aspect. In other words, the Constitution of Macedonia can be implemented in practice only under conditions where it is fully protected by unconstitutional acts and in particular by unconstitutional laws in this country. Unfortunately, we have often faced cases where laws heavily infringe the basic principles and provisions of this state.

Freedoms and rights represent the basic criteria on the citizen's position and role in the Republic of Macedonia. They are an integral part of the political history of this country, because they are the best indicator on the nature of the rapport between the state and the citizens, on one hand, and the state and other entities on the other hand. Precisely for this, human rights and freedoms of the citizens are an object of examination in this paper. Then again, the challenge of freedoms and rights has been a continuous demand of democratic forces, throughout the history of the existence of this country of over seventy years, including this day.

The present government yet continues to violate some of the freedoms and human rights in this country, and in this occasion we will focus on some of these violations which are most present in the country, like the right to anti-discrimination, presumption of innocence and the freedom of media.

Although the Republic of Macedonia within its 1991 Constitution has accepted the anti-discrimination clause foreseen under the Universal Declaration of Human Rights of 1948, it still fails to do much in respecting it entirely.

The anti-discrimination law in Macedonia is mostly expressed in the interethnic relations between Macedonians and Albanians, or specifically between the Macedonian Government and the Albanian people, as well as towards other ethnicities not belonging to the majority of people who live in the country. Often, the Albanians in this country have been subjected to discrimination in their fundamental rights by state authorities of this country. Therefore, the Republic of Macedonia, in order to build mutual multiethnic country needs to take measures towards the mitigation of differences in terms of the implementation of human freedom and rights. The presumption (assumption) of innocence of the citizen is an expression of respect towards the citizen, which often is brutally violated in this country. Many persons suspected and accused of various criminal offenses in Macedonia, during their deprivation of freedom, have been treated as guilty, whereas their guilt has not been established with a final court decision. The presumption of innocence in this country has been violated even in cases when persons who were illegally deprived of their freedom, arrested or tried not according to law, have not used their right to compensation for damage or other rights established by law.

Freedom of media and other forms of information represent another form of freedoms and rights which is also seriously violated in the Republic of Macedonia. We face violation of the right to expression and display of different opinions, views and stances, as well as violation to the right to democratic communication of the citizens with the authorities and vice versa.

The information media in Macedonia often misuse the freedom of information. The most usual cases of infringement to this freedom include: filtering of news in accordance with the needs of the existing government; commercialization of the information means and violation of the truth and the sound political judgment; silence the truth and manipulating public opinion; establishing a monopoly in the field of information, and finally, inducing hostility between the nations in Macedonia and planting hatred among them.

Despite the constitutional restrictions, even today there exists censorship in Macedonia, especially in the pro-government media or in the "independent" media, who adjust their editorial policy to the government's policy goals. 
Today in Macedonia in both local and national level, the media financed by the government and many other private media, through political marketing and the financial aids that they receive which aiming at their control, have been fully subjected to the present policy of the government. This absolute dependence has led to the lack of trust in the media by the majority of the citizens.

The bad rates of the media position in Macedonia from the legal practice perspective was also confirmed by a group of French and local experts during a debate organized in Skopje. In this occasion the French experts from Reporters without Borders presented their most recent index about the freedom of press for the year 2014. According to these results, Macedonia was ranked $123^{\text {rd }}$, thus marking a major drop of 84 places compared to their ranking from 4 years ago. During this debate it was concluded that the journalists in Macedonia are being faced with arrests, higher punishments against them, self-censorship, political pressures, etc. According to the French experts, Macedonia is in any case quite far from a kind of freedom of expression which would be acceptable in a European society. ${ }^{1}$

The European Court of Human Rights considers that the freedom of information is a basic element of democracy. Through its judgments, the European Court largely upheld the belief of Thomas Jefferson, a renowned former US President, in relation to the newspapers and the state government at the time in the United States of America, who emphasized that, "Were it left to me to decide whether we should have a government without newspapers, or newspapers without a government, I should not hesitate a moment to prefer the latter. ${ }^{2}$

In the Republic of Macedonia occurs the very opposite because the courts in this country have held a rather restrictive stand towards the journalists. This was seen during the trials against journalists accused of treason in 2005 and 2006, in which cases they all lost their court disputes against the President of the country, President of the Parliament of Republic of Macedonia, Prime Minister of Republic of Macedonia and against certain ministers. Despite the fact the trials in the Republic Macedonia are in general being processed very slowly, in these case the same were done in no time and with considerable penalties in cash to be paid by the journalists. ${ }^{3}$

LLLIn regard to theviolation of human rights in Macedonia, also spoke the Ombudsman through the presentation of his report in front of the members of parliament in June, 2015. Through this report he revealed many violations of human freedoms and rights in many of the segments of the country. ${ }^{4}$

In order to ensure full independence of the courts for Macedonia to function as a democratic state, it needs to fulfill some conditions:

- Firstly, emphasize the independence of the courts and the legislation, independence of the judiciary and legislation form the executive branch. This principle consists of independence of the courts from the parliament and the Government of Macedonia in particular, as well as eliminating the practice of political control over their work;

- Secondly, further depolarization of the courts in the country, hence forbidding any kind of political activity within the judicial organization, be it on party bases or other forms of political organization;

Thirdly, respecting the independent financing of the courts, meaning that the courts in the country, though financed through their independent budget, they keep being under permanent control of the government;

-Fourthly,thehigher respect for the judicial procedures is another condition in building independent judiciary and the legal state, in general;

- Fifth, the impartiality of judges, meaning that the judges need to be very impartial when bringing their decisions and this can be achieved only when they get elected based on merits which will make them dignified judges.

\footnotetext{
1 Debate organized in Skopje February $26^{\text {th }} .2014$, joint organization between the French Embassy in Macedonia, the International Institute for Human Rights and Peace in Cahn, and the Faculty of Law, "Justiniani I"

2 Thomas Jefferson, Writings, The Library of America, New York, 1984, p.117
}

${ }^{3}$ Svetomir Shkaric, Gordana Siljanovska-davkova, Ustavno pravo, Skopje, 2007, p.420

${ }^{4}$ See: The Report of the ombudsman presented in the Parliament of R. Macedonia, June 25th 2015. 
The "Sopot Case," as well as many other court cases in Macedonia, gives a lot of room to doubts about staged political trials, through the public disclosure of the wire taps called the "bombs" revealed by the leader of the opposition Zoran Zaev, during the past few months of 2015.

Another even bigger problem about the functioning of our courts is corruption. Half of the citizens of Macedonia consider that the judiciary is the most corrupted institution in the state. This was indicated in the recent reports of "Transparency International" which carried out surveys in many countries covering thousands of citizens. According to a report titled The 2009 Global Corruption Barometer, which was carried out from October 2008 until February 2009 in 69 states and territories, including 73 thousand surveyed people, over $50 \%$ of the citizens of Macedonia have picked out the judiciary as the most corrupted institution or field, responding to a question which included the political parties, the parliament, businesses and the public administration employees. For the most corrupted sector, $23 \%$ of the surveyed have chosen the public sector, $11 \%$ the political parties, $7 \%$ the business, $6 \%$ the Parliament and $3 \%$ chose the media. ${ }^{1}$

Another more controversial issue in the country which is directly related to the functioning of democracy and the constitutional state, are free and democratic elections.

Elections represent the foundation of the legitimacy of the state government, though often in Republic of Macedonia the same represent a process which is associated with questionable results of the participants in the elections and with major irregularities in the process of holding elections. The importance of elections, lays in the fact of how much indeed through them they express a higher articulation of the will of the citizens, of the political pluralism and of the democracy in Macedonia.

The organization of the several cycles of past elections in Republic of Macedonia has not been quite free and democratic. Through the wire taps known as "bombs" made public by the opposition leader Zoran Zaev, many suspicions have were raised about major manipulations during the election processes in the country. As a result of undemocratic processes of holding elections in the country we could notice the many frailties in the democratic character of the representing institutions in regard to the non-participation of the opposition in the parliament, the democratic way of exercising power, political rights of the citizens and the politics in general in Republic of Macedonia.

Also, as a result of such not very democratic elections in Macedonia, there is a failure in succeeding to exercise the controlling means for the work of the government in power. The importance of this issue is that by failing to have continuous control by the citizens over the people who govern, Macedonia has moved a lot towards an undemocratic system of governing in the last decade. Only through free and democratic elections in Macedonia we can speak of a legitimate government. Otherwise, as stressed by Altius, legitimacy aims at reducing the difficulties of both, those who govern and those being governed, "If consensus and the will of the leaders and the citizens is the same, in such cases the life of the people is rich and fortunate. ${ }^{2}$

Elections are important for Macedonia and every country because they link both the legitimacy and the legality of the state government.

Legality represents a judicial category, whereas legitimacy a politico-logical and sociological category. These two categories have their common and separate grounds among them. They come together when the legal state power is also legitimate. Simply put, the principal of legality or legitimacy means that the behavior of the state institutions during their exercise of power is in accordance with the positive rights, respectively with the law. Because of this, legitimacy is identified with legality. ${ }^{3}$

In these moments, Macedonia is in a very deep crisis of political institutions as a result of failure implementation of the laws, due to the lack of participation by the opposition within the works of the Parliament of Macedonia. In order for Macedonia to move out of this political institutional stalemate, the European Union has undertaken the initiative to resolve this problem through mediating between the parties, both the ruling and the opposition party.

\footnotetext{
${ }^{1}$ The 2009 Transparency InternationalReporton global corruption

2 Johanes Althusius, Politica metodicae digesta, London, 1964, p. 9

${ }^{3}$ Karl Joakim Fridrih, Konstitucionalizam (Ogranicavanje i kontrola vlasti), CIID Podgorica, 1996, str. 173
} 
The absence of rule of law is also one of the main remarks in the part of the report about Macedonia in regard to the current political situation published by the US State Department related to the freedoms and human rights in the world in June 2015. This stressed that, "The most emphasised problems dealing with human rights come as a result of the high level of corruption within the government and the lack to fully respect the rule of law, including here the continuous attempts to limit the freedom of media, interference in the judiciary and the selective punishment", claims the report. In addition, the Department of State notes that the judiciary in Macedonia is characterized by political influence, inefficiency and favouritism of persons already established in society, protracted processes and others. The State Department also notes that the police has used excessive physical violence against detainees and prisoners, as well as the poor conditions in prisons. The Department of State claims that there exists a government pressure over the media, where a number of persons close to the government are the owners of these media. ${ }^{1}$

Another proof about the lack of functionality of the legal state in Macedonia is also based on the reaction of the European Commission through the report presented by Mr. Pribe, over the political crisis in Macedonia during the beginning of 2015, which continues to escalate after the information made public by the opposition leader Zoran Zaev, according to whom the government in Macedonia has wire tapped over twenty thousand citizens, including important political dignitaries. The report reflects the legal violations, abuse of power and bad governance in Macedonia, including the prosecutor, courts, state security, electoral process, public service broadcaster, all the way to identifying the parties with state, reflecting all forms of destruction of fundamental principles of democracy and fundamental freedoms of human rights.Pribe's Report of the European Commission also gives guides on how to move out of the political institutional crisis with the wire tapping which has engrossed Macedonia. ${ }^{2}$

The lack of complete functioning of the legal state in Macedonia entails the lack of implementing the law in all the governmental institutions, both in terms of limiting their power and in terms of the procedures of their functionality. This also includes their responsibility for action or lack of action and illegal behaviors, like abuses, excess of powers etc.

The aim of the rule of law in Macedonia should consist more in the promotion and provision of legal protection of the citizens, their equality in front of the law, effective protection of all their freedoms and rights through independent and impartial courts. Macedonia needs to consider these important goals in its functioning as a legal state, in order to do more to ensure the same in a near future. This is a condition for the existence of political stability and security in this country.

1http://botasot.info/maqedonia/420903/departamenti-amerikan-ne-maqedoni-ka-korrupsion-dhe-nuk-sundon-ligji 2http://botasot.info/maqedonia/418334/komisioni-evropian-jep-direktivat-si-te-dilet-nga-kriza 